\title{
The Use of Bias-Corrected CMIP5 GCM Data to Analyse Temperature Variation in Puthimari River Basin- A Transnational Sub- Basin between Bhutan and India
}

\author{
Swapnali Barman ${ }^{1}$, Waikhom Rahul Singh ${ }^{2}$, Jaivir Tyagi $^{3}$ \\ ${ }^{1}$ Centre for Flood Management Studies, Guwahati, National Institute of Hydrology, India-781006, \\ swapnali.barman@gmail.com \\ ${ }^{2}$ Centre for Flood Management Studies, Guwahati, National Institute of Hydrology, India-781006, \\ wrsingh.nihr@gov.in \\ ${ }^{3}$ National Institute of Hydrology, Roorkee, India-24667, tyagi.nihr@gov.in
}

\begin{abstract}
Using five different CMIP5 climate models under the scenarios of RCP4.5 and RCP8.5, we analysed maximum, minimum and mean temperature over Puthimari river basin, that covers parts of Bhutan and North-eastern region of India. Historical period from 1970-2005 and future three periods, 2025-49, 2050-74 and 2075-99 were considered to understand the effect of global warming in the basin. Monthly Maximum, minimum and mean temperature variations analysis showed increase in temperature from 1970 to 2099 for all the models under both the scenarios. The study indicates that the average maximum, minimum and mean temperature over the basin will rise by $1.13-2.49^{\circ} \mathrm{C}$, $1.3-2.64^{\circ} \mathrm{C}$ and $1.21-2.6^{\circ} \mathrm{C}$ respectively from in $2075-99$ compared to the historical period under RCP 4.5. Again, these temperatures will increase by $2.68-3.89^{\circ} \mathrm{C}, 2.85-4.74^{\circ} \mathrm{C}$ and $2.76-4.53^{\circ} \mathrm{C}$ under RCP8.5 towards the end of the century. The linear trend analysis of maximum, minimum and mean temperature indicates rising trends in future over the basin.
\end{abstract}

Key words: Climate change, Temperature, Future projection, CMIP5, RCP, Puthimari

\section{INTRODUCTION}

Climate, in a broad sense, is the statistical mean and variability of relevant variables such as precipitation, temperature, humidity, atmospheric pressure, albedo that constitute weather and climate over a period of time ranging from months to thousands or millions of years [1]. Various scientific assessment in the past demonstrated that earth's climate has been changed on both global and regional scales since the start of industrial era. Accelerated change in climate is expected to have major impact on the future sustainability of the earth [2], [3]. The change in the global environment due to climate change may lead to environmental disasters [4]. Increase in anthropogenic emissions of gases into the atmosphere, and an enhanced greenhouse effect are the major driving forces behind the accelerated global warming that has taken place over the last century [5], [6]. Global warming will alter the radiation balance of the atmosphere. This in turn will cause increase in average temperature of the earth and changes in precipitation pattern and other climatic variables [7]. Higher greenhouse gas concentrations have trapped more thermal radiation and consequently warmed the planet [8].Climate change projection study is important to assess its impact and to take proper management strategies [9].In its Fifth Assessment Report, the Intergovernmental Panel on Climate Change reported that average combined land and sea surface temperature warmed between $0.65^{\circ} \mathrm{C}$ and $1.06^{\circ} \mathrm{C}$ from 1880 to 2012 [10].[10]also reported that during the period from 1951 to 2010, the number of warm days and nights has increased, and number of cold days and nights has decreased across the globe. The increasing trend of temperature will accelerate more towards the end of $21^{\text {st }}$ century and the temperature may increase by $5.5^{\circ} \mathrm{C}[11]$, [12]. [13]indicated an increase in global average temperature by 4$5^{\circ} \mathrm{C}$ compared to the pre-industrial era that will lead to rise in the sea level by $10-60 \mathrm{~m}$.

In context of India, the vast population of the country depends on sectors such as agriculture, forestry, animal husbandry and fisheries for their livelihood. The production of these sectors is very sensitive to the change in climate which may come in the form of fall in precipitation and rise in temperature. [14]mentioned a report from IPCC which projects the increase of global mean temperature between $1.4^{\circ} \mathrm{C}$ and $5.8^{\circ} \mathrm{C}$ by 2100 . The study stated that the impact of this unprecedented increase in global temperature would be severe in the tropical areas including India. [15] analysed the surface temperature trends over India during the period 1901 to 2003 and found that the mean annual temperature has increased at the rate of $0.05^{\circ} \mathrm{C}$ per decade. During the years from 1891 to 2009,23 numbers of large-scale droughts have occurred in India where the frequency of droughts is increasing, posing a grave threat to agriculture and food security [16].The seasonal and annual temperature over India has increased significantly during the period 1901-2007 with increase in mean temperature by $0.003^{\circ} \mathrm{C} /$ year [17]. Northeastern region of India is one of the most vulnerable part to climate change that impacts the hydrology and water resources of the region. Using the India Meteorological Department (IMD) gridded data,[18] analysed the annual mean temperature, and annual minimum and maximum temperature over northeast India. They showed that during the period 1971 to 2005 , the annual mean temperature possessed a significant increasing trend. Annual minimum 
Swapnali Barman et al., International Journal of Emerging Trends in Engineering Research, 9(2), February 2021,132 - 139

temperature significantly increased at the rate of $0.04^{\circ} \mathrm{C} /$ year while the annual maximum temperature does not show significant trend. [19] showed that the average temperature over North-eastern part of India will be $2^{\circ} \mathrm{C}$ higher in 2050 as compared to the temperature records from 1950-2000. [20]found that maximum, minimum and mean temperature over northeast India during the period 1901 to 2003 has increased in all the seasons viz. monsoon, pre-monsoon, post-monsoon and winter. A study by [21]suggested that precipitation over this part of the country has decreased by $355.6 \mathrm{~mm}$ during 1979 to 2014 indicating rapid drying.

Puthimari is a major north bank tributary of mighty river Brahmaputra covering part of Bhutan and north-eastern part of India. The impact of climate change on the basin of Puthimari river is important to understand the future hydrology of the river. The change in watershed hydrology due to global warming is important for proper water management. The main driving force of climate change is temperature, and determining the change in temperature due to global warming is the first step to any climate change impact study. Projected temperature trend analysis is important to assess the impact climate change in the field of agriculture and hydrology [22].In last few decades, the settlement in the basin has increased significantly leading to decrease in the forest cover area. This has led to a warmer climate in the basin. This study aims at analysing the future temperature over Puthimari basin under RCP4.5 and RCP8.5 for different climate models of Coupled Model Intercomparison Project 5 (CMIP5).

\section{MATERIALS AND METHODOLOGY}

The study area Puthimari basin is shown in Figure1.



Figure 1: The Puthimari river basin showing its position between Bhutan and India

The basin has an area of approximately $3681.39 \mathrm{Km}^{2}$. Bias corrected statistically downscaled minimum and maximum daily surface air temperature for five different CMIP5 climate models available at $25 \mathrm{~km}$ x $25 \mathrm{~km}$ spatial resolutions have been downloaded from the web portal of NASA Centre for Climate Simulation. The study has been conducted under two Representative Concentration Pathways (RCP), RCP4.5 and RCP8.5. Table 1 gives the list of climate models considered for this study along with their spatial resolutions.
Table 1: CMIP5 climate models with resolutions

\begin{tabular}{|l|l|c|c|}
\hline \multicolumn{1}{|c|}{$\begin{array}{c}\text { Sl. } \\
\text { No. }\end{array}$} & \multicolumn{1}{|c|}{ Model } & $\begin{array}{c}\text { Latitude } \\
(\mathrm{deg})\end{array}$ & $\begin{array}{c}\text { Longitude } \\
(\mathrm{deg})\end{array}$ \\
\hline 1. & CCSM4 & 0.9424 & 1.25 \\
\hline 2. & MRI-CGCM3 & 1.12148 & 1.125 \\
\hline 3. & MIROC5 & 1.4008 & 1.40625 \\
\hline 4. & MPI-ESM-MR & 1.8653 & 1.875 \\
\hline 5. & INMCM4 & 1.5 & 2.0 \\
\hline
\end{tabular}

Change in temperature over Puthimari basin has been carried out in five different time periods. The first period is the historical period from 1970 to 2005 . The future up to 2099 has been divided into three time periods, each of 25 years durations viz., 2025-49, 2050-74 and 2075-99. Both the maximum and minimum temperature variations have been observed for each month. The change in average maximum and minimum temperature from one time period to another as well as the years of occurrence of highest maximum and highest minimum temperature in each time period has been determined. Moreover, the variations in monthly mean temperature during different time periods have been analysed for each model from which the warmest year having the highest mean temperature in each period has been found out. All these analyses were performed for RCP 4.5 and RCP 8.5 separately. A linear trend analysis of future projected maximum, minimum and mean temperature for the selected models has been performed to check the effect of the two selected scenarios on future temperature over the basin.

\section{RESULTS AND DISCUSSIONS}

\subsection{Temperature analysis for $\mathrm{RCP} 4.5$}

Monthly average maximum and minimum temperature variations for the models in each time period are represented graphically in Figure 2. Compared to the historical period, future warmer climate is observed for each of the model.


for the climate models in each time period for RCP 4.5 
Periodical analysis showed that both monthly maximum and minimum temperature rise continuously from 2025 to 2099 for most of the models. Exceptions are observed in certain models for few different months. For instance, in case of CCSM4, maximum temperature during 2075-99 decreases compared to the previous period in the months of November and December. Similarly, minimum temperature for this model as well as for INMCM4 show continuous decrease from 2025 to 2099 in September, October, November and December. For MRICGCM3 and MIRPC5, maximum temperature is less during 2050-74 compared the previous period 2025-49 in the month of March and April respectively. Also, minimum temperature for MIROC5 and maximum temperature for INMCM4 decreases continuously from 2025 to 2099 in the month of October. For most of the models, the highest maximum temperature is observed in the month of August except that during 2050-74, the maximum temperature will occur in the months of June and July respectively for MRICGCM3 and MIROC5. Also, during 2075-99, July will be the warmest month for MIROC5 and MPIESM. The highest maximum temperature will be between $28.5^{\circ} \mathrm{C}$ and $31.02^{\circ} \mathrm{C}$ for different models compared to historical period temperature of $27.89-28.36^{\circ} \mathrm{C}$. The highest minimum temperature for most of the models will occur in the month of July including the historical period except for MPIESM where the minimum temperature will be highest from 2025 to 2074 in the month of August. Compared to historical highest minimum temperature of $20.61-20.84^{\circ} \mathrm{C}$, it is projected to increase to $21.223 .34^{\circ} \mathrm{C}$ in future. The year of occurrence of highest maximum and minimum temperature under RCP 4.5 in different time periods for the selected models are tabulated in Table2a and $2 \mathrm{~b}$ respectively.

Table 2a:Years of highest maximum temperature under RCP4.5

\begin{tabular}{|c|c|c|c|c|}
\hline \multirow{2}{*}{$\begin{array}{l}\text { Climate } \\
\text { models' } \\
\text { Sl. No. }\end{array}$} & \multicolumn{4}{|c|}{$\begin{array}{c}\text { Highest Maximum Temperature } \\
\text { (Temperature in }{ }^{\circ} \mathrm{C} \text { ) }\end{array}$} \\
\cline { 2 - 5 } & $1970-2005$ & $2025-49$ & $2050-74$ & $2075-99$ \\
\hline 1. & 1995 & 2038 & 2069 & 2088 \\
& $(25.75)$ & $(26.88)$ & $(27.65)$ & $(27.94)$ \\
\hline 2. & 1979 & 2045 & 2074 & 2098 \\
& $(23.95)$ & $(26.39)$ & $(27.04)$ & $(27.24)$ \\
\hline 3. & 1971 & 2034 & 2070 & 2087 \\
& $(23.16)$ & $(26.63)$ & $(27.33)$ & $(27.50)$ \\
\hline 4. & 1987 & 2049 & 2056 & 2078 \\
& $(25.96)$ & $(27.40)$ & $(28.08)$ & $(28.57)$ \\
\hline 5. & 1995 & 2042 & 2073 & 2099 \\
& $(25.86)$ & $(26.61)$ & $(26.78)$ & $(27.42)$ \\
\hline
\end{tabular}

Table 2b:Years of highest minimum temperature under RCP4.5

\begin{tabular}{|c|c|c|c|c|}
\hline \multirow{2}{*}{$\begin{array}{l}\text { Climate } \\
\text { models' } \\
\text { Sl. No. }\end{array}$} & \multicolumn{4}{|c|}{$\begin{array}{l}\text { Highest Minimum Temperature } \\
\left(\text { Temperature in }{ }^{\circ} \mathrm{C}\right)\end{array}$} \\
\hline & $1970-2005$ & $2025-49$ & $2050-74$ & $2075-99$ \\
\hline 1. & $\begin{array}{c}2002 \\
(15.53)\end{array}$ & $\begin{array}{c}2038 \\
(16.71) \\
\end{array}$ & $\begin{array}{c}2069 \\
(16.73) \\
\end{array}$ & $\begin{array}{c}2099 \\
(17.32) \\
\end{array}$ \\
\hline 2. & $\begin{array}{l}1996 \\
(15.12)\end{array}$ & $\begin{array}{c}2049 \\
(16.03)\end{array}$ & $\begin{array}{c}2072 \\
(16.54)\end{array}$ & $\begin{array}{c}2098 \\
(16.74)\end{array}$ \\
\hline 3. & $\begin{array}{l}1976 \\
(15.08)\end{array}$ & $\begin{array}{c}2049 \\
(16.44)\end{array}$ & $\begin{array}{c}2070 \\
(16.92)\end{array}$ & $\begin{array}{c}2085 \\
(17.36)\end{array}$ \\
\hline 4. & $\begin{array}{l}2003 \\
(15.22)\end{array}$ & $\begin{array}{c}2047 \\
(16.80)\end{array}$ & $\begin{array}{c}2061 \\
(17.75)\end{array}$ & $\begin{array}{c}2078 \\
(17.86)\end{array}$ \\
\hline 5. & $\begin{array}{c}1987 \\
(15.81)\end{array}$ & $\begin{array}{c}2033 \\
(15.88)\end{array}$ & $\begin{array}{l}2073 \\
(16.17)\end{array}$ & $\begin{array}{l}2099 \\
(17.05)\end{array}$ \\
\hline
\end{tabular}

In the historical period, the highest maximum temperature for the models varied between $23.16^{\circ} \mathrm{C}$ (MIROC5)-25.96 ${ }^{\circ} \mathrm{C}$ (MPIESM) and it mostly occurred in between 1987 and 1995. Only MIROC5 showed the warmest year in 1971. The models indicate that during 2025-49, 2038, 2045, 2034, 2049 and 2042 will be the warmest year for models 1-5 respectively. The highest maximum temperature during this period ranges between $26.39^{\circ} \mathrm{C}($ MRICGCM3)$27.40^{\circ} \mathrm{C}(\mathrm{MPIESM})$. During 2050-74, the maximum temperature range increases to $26.78^{\circ} \mathrm{C}$ (INMCM4) $28.08^{\circ} \mathrm{C}$ (MPIESM) and occurs mostly after 2069 except MPIESM for which 2056 is observed as the warmest year. The highest maximum temperature for the models during the last period of the century is projected to rise between $27.24^{\circ} \mathrm{C}$ (MRICGCM3) and $28.57^{\circ} \mathrm{C}$ (MPIESM), and occurs after 2075. The highest minimum temperature under RCP 4.5 during 1970-2005 varied between $15.08-15.81^{\circ} \mathrm{C}$ and observed mostly after 1985 . The range of highest minimum temperature during 2025-49, 2050-74 and 2075-99 are observed to be in the range of $15.88^{\circ} \mathrm{C}$ (INMCM4, 2033) $16.80^{\circ} \mathrm{C}(\mathrm{MPIESM}, 2047), \quad 16.17^{\circ} \mathrm{C}$ (INMCM4, 2073)$17.75^{\circ} \mathrm{C}$ (MPIESM, 2061) and $16.74^{\circ} \mathrm{C}$ (MRICGCM3, 2098) $-17.86^{\circ} \mathrm{C}(\mathrm{MPIESM}, 2078)$ respectively.

Figure 3 shows the increase in average (a) maximum and (b) minimum temperature from one time period to another for RCP4.5.

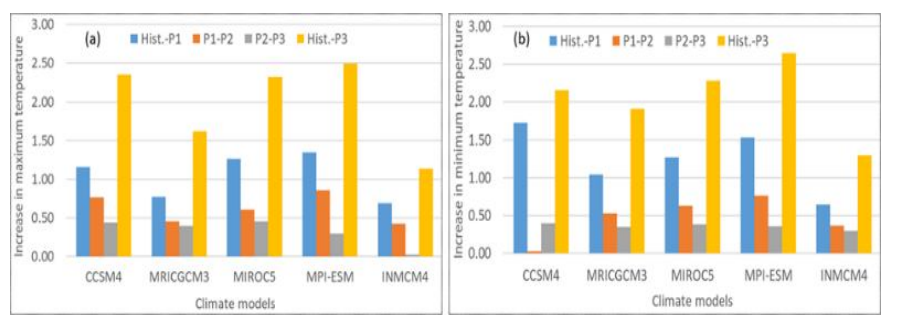

Figure 3: Increase in average maximum and minimum temperature from one time period to another for RCP 4.5

In the figure, P1, P2 and P3 denote the periods 2025-49, 2050-74 and 2075-99 respectively. Increase in both maximum and minimum temperature is observed between two consecutive time periods for each model. The temperature difference decreases subsequently from P1 to P3 except for CCSM4 where the increase in average minimum temperature from $\mathrm{P} 1$ to $\mathrm{P} 2$ is less than that from $\mathrm{P} 2$ to $\mathrm{P} 3$. Compared to the historical period, the average maximum and minimum temperature over the basin are projected to increase by $1.13-2.49^{\circ} \mathrm{C}$ and $1.3-2.64^{\circ} \mathrm{C}$ respectively for the selected models towards the end of the century.

The mean temperature over the basin has also been analysed for the different climate models. Figure4 gives the change in monthly mean temperature in different time periods for the models under RCP4.5. 
Swapnali Barman et al., International Journal of Emerging Trends in Engineering Research, 9(2), February 2021,132 - 139

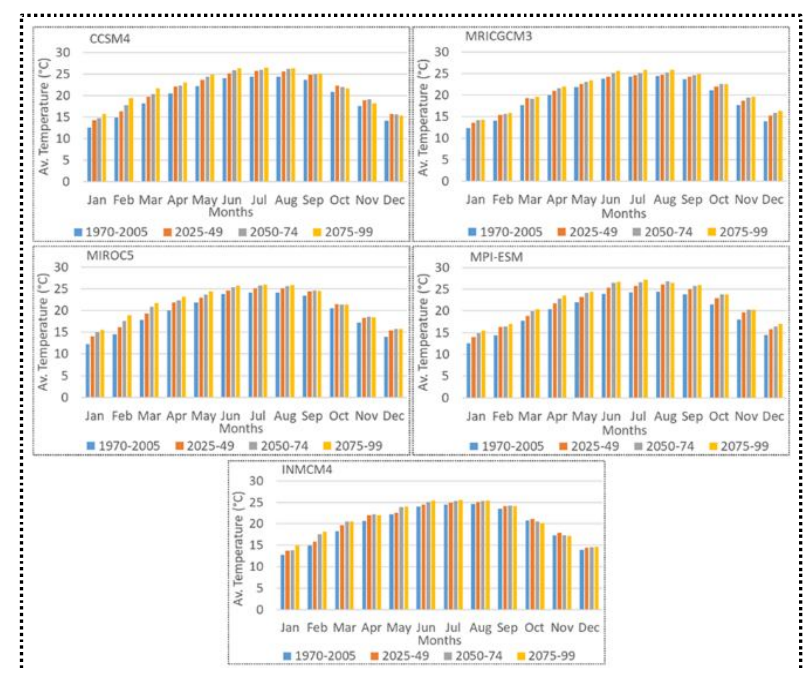

Figure 4: Mean monthly temperature variations for the models under RCP 4.5

Except for INMCM4, for rest of the models, there will be a continuous rise in temperature from 2025 to 2099 in each month. In case of INMCM4, gradual decrease in future temperature is observed for the months of October and November. Except for CCSM4 during 2025-49 and MIRPC5 during 2050-74 where themaximum mean temperature is seen in July, for all other models the temperature will be maximum in the month of August during 2025-49 and 205074. During 2075-99 however, the maximum temperature will shift to the month of July except for majority of the models. The maximum mean monthly temperature for the models will lie between $24.84^{\circ} \mathrm{C}-27.18^{\circ} \mathrm{C}$ compared to the historical period range of $24.21-24.54^{\circ} \mathrm{C}$. The minimum mean temperature in all the time periods for the models are observed in the month of January. Table 3 shows the years of occurrence of maximum mean temperature for different time periods under RCP4.5.

Table 3 Years of occurrence of maximum mean temperature for RCP 4.5

\begin{tabular}{|c|c|c|c|c|}
\hline \multirow{2}{*}{$\begin{array}{l}\text { Climate } \\
\text { models' } \\
\text { Sl. No. }\end{array}$} & \multicolumn{4}{|c|}{$\begin{array}{l}\text { Maximum mean temperature } \\
\left(\text { Temperature in }{ }^{\circ} \mathrm{C}\right)\end{array}$} \\
\hline & $1970-2005$ & $2025-49$ & $2050-74$ & $2075-99$ \\
\hline 1. & $\begin{array}{l}2002 \\
(20.53)\end{array}$ & $\begin{array}{l}2038 \\
(21.79)\end{array}$ & $\begin{array}{c}2069 \\
(22.19)\end{array}$ & $\begin{array}{c}2087 \\
(22.44)\end{array}$ \\
\hline 2. & $\begin{array}{c}1979 \\
(19.33)\end{array}$ & $\begin{array}{c}2049 \\
(20.91)\end{array}$ & $\begin{array}{c}2074 \\
(21.74)\end{array}$ & $\begin{array}{c}2098 \\
(21.99)\end{array}$ \\
\hline 3. & $\begin{array}{l}1988 \\
(18.69)\end{array}$ & $\begin{array}{l}2049 \\
(21.41)\end{array}$ & $\begin{array}{c}2070 \\
(22.12)\end{array}$ & $\begin{array}{c}2099 \\
(22.37)\end{array}$ \\
\hline 4. & $\begin{array}{c}2004 \\
(20.49)\end{array}$ & $\begin{array}{l}2049 \\
(21.93)\end{array}$ & $\begin{array}{c}2061 \\
(22.74)\end{array}$ & $\begin{array}{c}2078 \\
(23.21)\end{array}$ \\
\hline 5. & $\begin{array}{c}1988 \\
(20.72)\end{array}$ & $\begin{array}{c}2033 \\
(21.23)\end{array}$ & $\begin{array}{l}2073 \\
(21.48)\end{array}$ & $\begin{array}{c}2099 \\
(22.23)\end{array}$ \\
\hline
\end{tabular}

During 2025-49, for models 2, 3 and 4, the warmest year be 2049, and for models 1 and 5, the warmest year are 2038 and 2033 respectively. The maximum mean temperature will remain between $20.91^{\circ} \mathrm{C}$ and $21.93^{\circ} \mathrm{C}$. During $2050-74$, for each model the maximum mean temperature $\left(21.48-22.74^{\circ} \mathrm{C}\right)$ is observed in 2069, 2074, 2070, 2061 and 2073 respectively for models 1 to 5 . In the end period, for models 3 and 5 maximum mean temperature is observed in 2099, while for models 1, 2 and 4 it is observed in 2087, 2098 and 2078 respectively. The maximum temperature lies between $21.99^{\circ} \mathrm{C}$ and $23.21^{\circ} \mathrm{C}$.

Figure5 gives the graphical representation of increase in mean temperature from one time period to another for RCP 4.5.

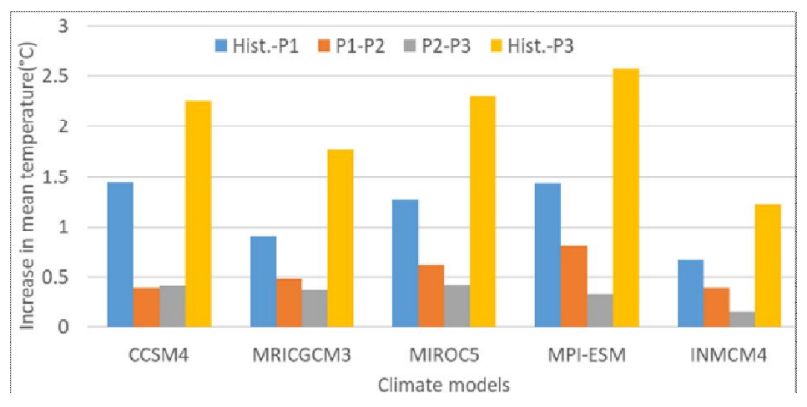

Figure 5: Increase in average mean temperature between different time periods for RCP 4.5

It is clear from the figure that for different models, mean temperature over the basin will rise by $1.21-2.6^{\circ} \mathrm{C}$ towards the end of the century as compared to the historical period. However, the increased value of temperature goes on diminishing between two consecutive time periods.

\subsection{Temperature analysis for RCP 8.5}

Similar analysis for future temperaturehasbeen carried out for RCP8.5. Figure 6 shows the monthly average maximum and minimum temperature for different time periods for the models under RCP8.5.

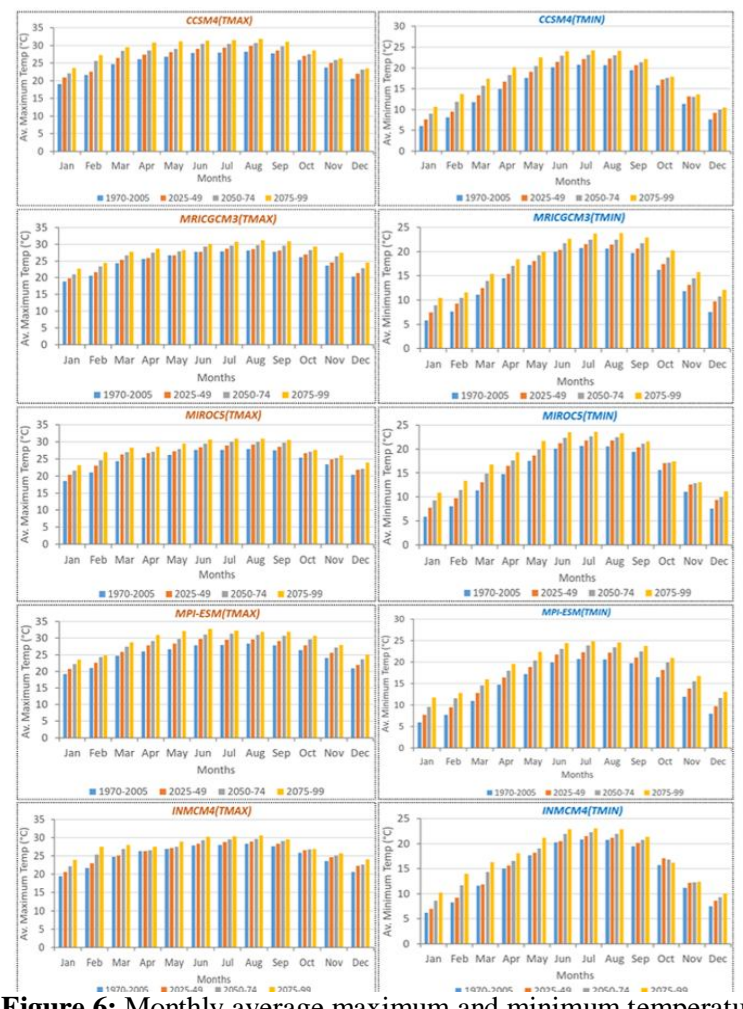

Figure 6: Monthly average maximum and minimum temperature for the climate models in each time period for RCP 8.5 
Unlike RCP4.5, no exception can be seen in any of the models and for all of them temperature increases continuously from the historical period to the end of the century. For most of the models, the highest maximum and minimum temperature will be observed in the month of August and July respectively. Exceptions are for MRICGCM3 where highest maximum temperature during 2025-49 will occur in July, and for MPIESM it will occur in the months of June (2025-49) and July (2050-74). For CCSM4 during 2050-74, and for MRICGCM3 from 2050-99, the highest minimum temperature is observed in the month of August. The highest monthly maximum (minimum) temperature is observed between $28.63-32.77^{\circ} \mathrm{C}(21.50$ $24.85^{\circ} \mathrm{C}$ ) compared to historical period temperature of 27.89 $28.36^{\circ} \mathrm{C}\left(20.61-20.84^{\circ} \mathrm{C}\right)$.

The year of occurrence of highest maximum and minimum temperature for RCP 8.5 are as shown in Table $4 \mathrm{a}$ and $4 \mathrm{~b}$ respectively.

Table 4a:Years of highest maximum temperature under RCP8.5

\begin{tabular}{|c|c|c|c|c|}
\hline Climate & \multicolumn{4}{|c|}{$\begin{array}{c}\text { Highest Maximum Temperature } \\
\text { models' }\end{array}$} \\
\cline { 2 - 5 } Sl. No. & $1970-2005$ & $2025-49$ & $2050-74$ & $2075-99$ \\
\hline 1. & 1995 & 2047 & 2074 & 2096 \\
& $(25.75)$ & $(26.96)$ & $(28.33)$ & $(30.14)$ \\
\hline 2. & 1979 & 2047 & 2072 & 2096 \\
& $(23.95)$ & $(26.64)$ & $(27.86)$ & $(29.25)$ \\
\hline 3. & 1971 & 2041 & 2055 & 2098 \\
& $(23.16)$ & $(26.76)$ & $(27.63)$ & $(29.07)$ \\
\hline 4. & 1987 & 2049 & 2071 & 2094 \\
& $(25.96)$ & $(27.74)$ & $(28.96)$ & $(30.49)$ \\
\hline 5. & 1995 & 2047 & 2073 & 2099 \\
& $(25.86)$ & $(26.47)$ & $(27.40)$ & $(28.78)$ \\
\hline
\end{tabular}

Table 4b:Years of highest minimum temperatureunder RCP8.5

\begin{tabular}{|c|c|c|c|c|}
\hline \multirow{2}{*}{$\begin{array}{l}\text { Climate } \\
\text { models' } \\
\text { Sl. No. }\end{array}$} & \multicolumn{4}{|c|}{$\begin{array}{c}\text { Highest Minimum Temperature } \\
\left.\text { (Temperature in }{ }^{\circ} \mathrm{C}\right)\end{array}$} \\
\cline { 2 - 5 } & $1970-2005$ & $2025-49$ & $2050-74$ & $2075-99$ \\
\hline 1. & 2002 & 2048 & 2074 & 2099 \\
& $(15.53)$ & $(16.65)$ & $(18.06)$ & $(19.27)$ \\
\hline 2. & 1996 & 2041 & 2072 & 2096 \\
& $(15.12)$ & $(16.37)$ & $(17.63)$ & $(18.96)$ \\
\hline 3. & 1976 & 2044 & 2068 & 2098 \\
& $(15.08)$ & $(16.53)$ & $(17.44)$ & $(18.83)$ \\
\hline 4. & 2003 & 2047 & 2073 & 2098 \\
& $(15.22)$ & $(17.00)$ & $(18.87)$ & $(20.14)$ \\
\hline 5. & 1987 & 2046 & 2061 & 2099 \\
& $(15.81)$ & $(16.24)$ & $(17.41)$ & $(18.77)$ \\
\hline
\end{tabular}

It can be observed from Table 4 that during 2025-49, for RCP 8.5, the highest maximum temperature will occur between 2040-49 for all the models and maximum temperature lies between $26.47^{\circ} \mathrm{C}$ and $27.74^{\circ} \mathrm{C}$. During the next time period from 2050-74, the highest maximum temperature is observed in range $27.40-28.96^{\circ} \mathrm{C}$ and occurs between 2070 and 2074 for the models except for MIROC5. During the last time period from 2075-99, the highest maximum temperature is observed between 2094-99 for the models. The highest maximum temperature in this period will lie between $28.78^{\circ} \mathrm{C}$ and $30.49^{\circ} \mathrm{C}$. Again, the highest minimum temperature during $2025-49\left(16.24-17^{\circ} \mathrm{C}\right)$ will occur in between 2040 and 2049. During 2050-74 (17.41$18.87^{\circ} \mathrm{C}$ ) it occurs between 2060 and 2074 . In the end period, highest minimum temperature in the range of 18.77$20.14^{\circ} \mathrm{C}$ is observed only after 2095 for all the models.

The increase in (a) maximum and (b) minimum temperature between two consecutive time periods for different models under RCP8.5 are shown in Figure 7.Compared to the historical period, the maximum temperature will increase by $2.68-3.89^{\circ} \mathrm{C}$ towards the end of the century. The minimum temperature will increase by $2.85-4.74^{\circ} \mathrm{C}$ from 1970 to 2099. For each time period, both maximum and minimum temperature increases with different values of increased temperature compared to its previous time period.

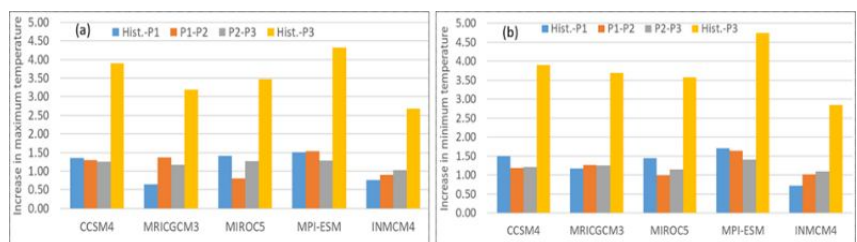

Figure 7: Increase in average maximum and minimum temperature from one time period to another for RCP 4.5

Figure 8 shows the monthly mean temperature in different time periods for the models under RCP8.5.

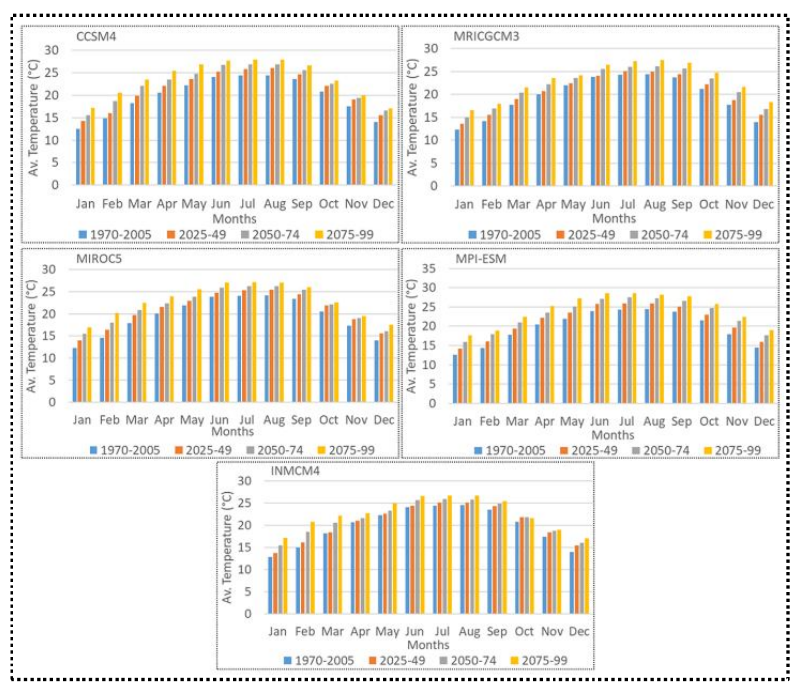

Figure 8: Mean monthly temperature variations for the models under RCP 8.5

For each month, all the models show continuous increase in temperature from 2025 to 2099 . The maximum temperature in different time periods will occur mostly in the month of July and August for the models except that, for MPI-ESM during 2075-99, maximum temperature is observed in the month of June. The maximum mean monthly temperature from 2025 to 2099 will vary between $25.07-28.59^{\circ} \mathrm{C}$ for the models with the lowest and highest shown by MRICGCM3 and MPIESM respectively.Table5 gives the year for maximum mean temperature under RCP 8.5 for the models during different time periods. 
Swapnali Barman et al., International Journal of Emerging Trends in Engineering Research, 9(2), February 2021,132 - 139

Table 5: Years of occurrence of maximum mean temperature for

\begin{tabular}{|c|c|c|c|c|}
\hline \multirow{2}{*}{$\begin{array}{l}\text { Climate } \\
\text { models' }\end{array}$} & \multicolumn{4}{|c|}{$\begin{array}{c}\text { Maximum mean temperature } \\
\left.\text { (Temperature in }{ }^{\circ} \mathrm{C}\right)\end{array}$} \\
\cline { 2 - 5 } Sl. No. & $1970-2005$ & $2025-49$ & $2050-74$ & $2075-99$ \\
& & & & \\
\hline 1. & 2002 & 2049 & 2074 & 2096 \\
& $(20.53)$ & $(21.65)$ & $(23.19)$ & $(24.67)$ \\
\hline 2. & 1979 & 2047 & 2072 & 2096 \\
& $(19.33)$ & $(21.29)$ & $(22.75)$ & $(24.11)$ \\
\hline 3. & 1988 & 2044 & 2072 & 2098 \\
& $(18.69)$ & $(21.64)$ & $(22.44)$ & $(23.95)$ \\
\hline 4. & 2004 & 2047 & 2073 & 2098 \\
& $(20.49)$ & $(22.32)$ & $(23.91)$ & $(25.27)$ \\
\hline 5. & 1988 & 2046 & 2073 & 2099 \\
& $(20.72)$ & $(21.33)$ & $(22.33)$ & $(23.78)$ \\
\hline
\end{tabular}

During 2025-49, the maximum mean temperature that lies between $21.33^{\circ} \mathrm{C}$ and $22.32^{\circ} \mathrm{C}$ is observed after 2043 for the models. For the next time period, maximum mean temperature of $22.33-23.91^{\circ} \mathrm{C}$ is observed after 2070 . For the last period 2075-99, the maximum mean temperature occurs after 2095 with temperature ranging from $23.78^{\circ} \mathrm{C}$ to $25.27^{\circ} \mathrm{C}$. It is also observed that during each time period, the maximum mean temperature is lowest for INMCM4 and highest for MPIESM.

Figure 9 shows the graphical representation of increase in average mean temperature between two consecutive time periods under RCP 8.5 .

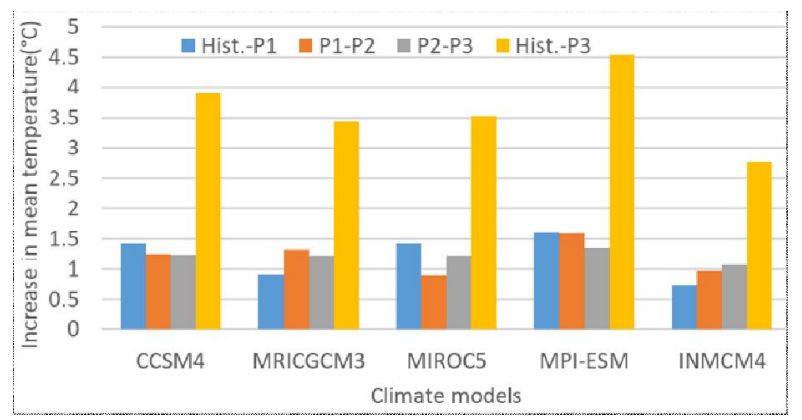

Figure 9: Increase in average mean temperature between different time periods for RCP 8.5

From historical to $\mathrm{P} 1, \mathrm{P} 1$ to $\mathrm{P} 2$ and $\mathrm{P} 2$ to $\mathrm{P} 3$, mean temperature will increase by $0.74-1.6^{\circ}, 0.89-1.5^{\circ}$ and $1.06-$ $1.34^{\circ}$ for the various models. Compared to the historical period, the mean temperature is projected to increase by $2.76-4.53^{\circ}$ towards the end of the century.

\subsection{Linear trend analysis of future temperature for RCP 4.5 and RCP 8.5}

A linear trend analysis has been performed to check the trends of maximum, minimum and mean temperature from 2025 to 2099 under RCP 4.5 and RCP8.5 as shown in Figure 10.

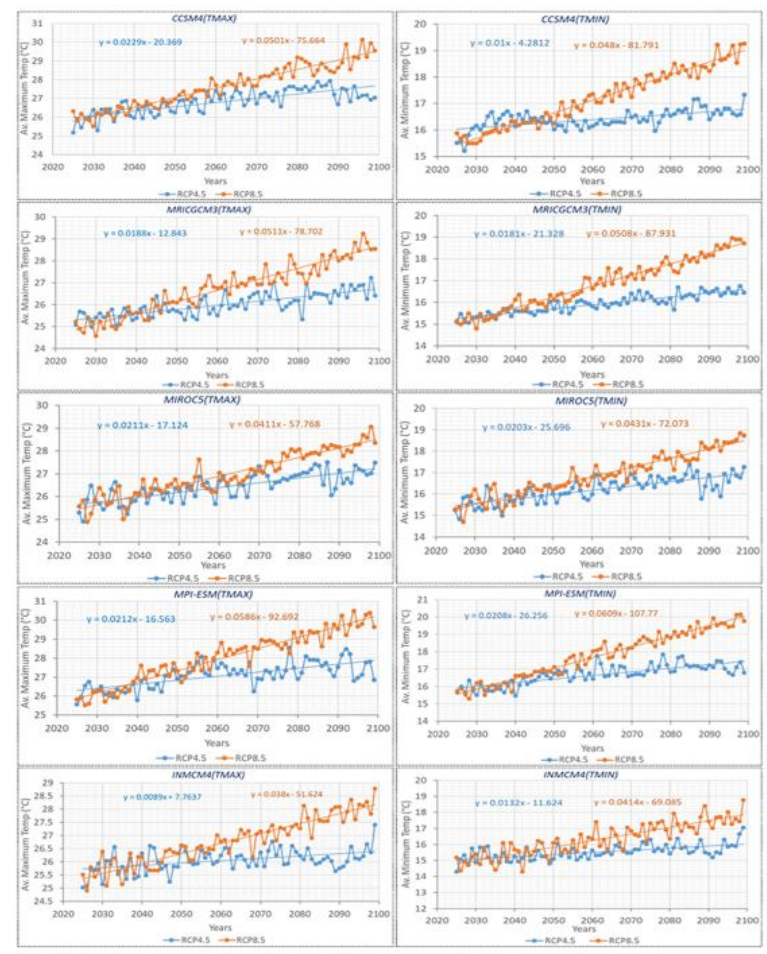

Figure 10: Linear trend analysis of future maximum and minimum temperature under RCP 4.5 and RCP 8.5

Rising trends of both maximum and minimum temperature is observed for all the models under both the RCPs with steeper trend under RCP8.5. Similar results are observed for the trends in future mean temperature as shown in Figure 11.

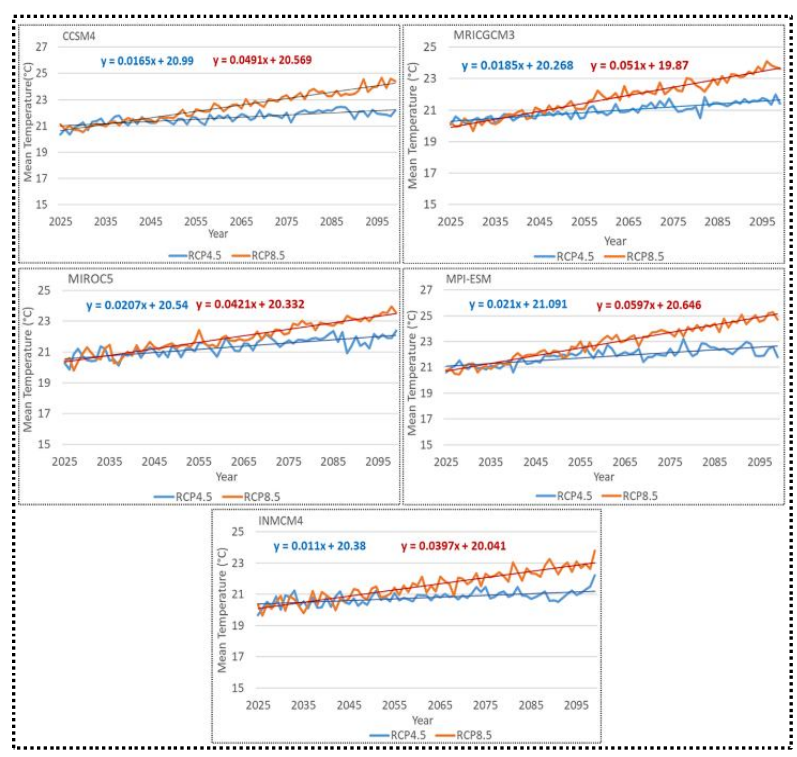

Figure 11: Linear trend analysis of future mean temperature under RCP 4.5 and RCP 8.5

For all the models, very insignificant rise in projected mean temperature can be noticed under RCP4.5 and RCP8.5. However, under RCP8.5 scenario, the rising trend is little steeper compared to that under RCP4.5.

The results of the analyses carried out using different climate models for maximum, minimum and mean temperature are 
with the agreement that the future temperature will increase over the Puthimari basin under RCP 4.5 and RCP 8.5 scenarios. Although the north-eastern part of India is not yet explored rigorously in terms of climate change impacts, few researchers found similar kind of trends in temperature over this region. [23]carried out a trend analysis of temperature over northeast India and found that except certain regions, for other parts rising trends were observed for both maximum and minimum temperature. Again,[24]used IMD dataset from 1971-2007 and found increasing trend of maximum temperature at a rate of between 0.5-1.6/100 year with highest and lowest increase in winter and pre-monsoon season respectively over northeast India. [25]from his study indicated that the annual mean temperature over northeast India is rising at the rate of 0.04. The upper part of Puthimari catchment falls in Bhutan. Studies conducted for future temperature projection over Bhutan indicates rise in maximum, minimum and mean temperature under RCP 4.5 and RCP 8.5 [26].[27]also indicated rise in temperature over Bhutan during last few decades. The Puthimari basin is important in terms of its hydrological impacts on the mainstream Brahmaputra and being a part of Brahmaputra basin, Puthimari is also highly influenced by climate change which affects the hydrological behaviour of the river. Change in temperature due to global warming is the main driving force of climate change. Analysis of present and future variability of climate over the basin is thus important for future watershed management.

\section{CONCLUSIONS}

The study has been carried out to analyse change in future temperature under two different scenarios, RCP 4.5 and RCP 8.5 , over Puthimari river basin, a major transboundary basin of Brahmaputra covering parts of the countries Bhutan and India. We analysed the change in maximum, minimum and mean temperature all over the basin by considering five climate models of CMIP5. Historical temperature from 1970 to 2005 , and future temperature for different periods viz., 2025-49, 2050-74 and 2075-99 has been considered for the analysis. All the models agreed to the fact that the future temperature over the basin will increase under the two climate change scenarios. The warmest months in future will remain from June to August. Compared to the historical period, where the highest maximum (minimum) temperature for the models lied between $23.16-25.96^{\circ} \mathrm{C}\left(15.08-15.81^{\circ} \mathrm{C}\right)$, it will rise to $27.24-28.57^{\circ} \mathrm{C}\left(16.74-17.86^{\circ} \mathrm{C}\right)$ towards the end of the century under RCP 4.5. There will be an increase in the average maximum (minimum) temperature by 1.13 $2.49^{\circ} \mathrm{C}\left(1.3-2.64^{\circ} \mathrm{C}\right)$ during $2075-99$ from $1970-2005$. The mean temperature over the basin however will rise by 1.21 $2.6^{\circ} \mathrm{C}$ in $2075-99$ as compared to the historical period.

Under the scenario of RCP 8.5, in the last period of the century, the basin will experience highest maximum (minimum) temperature of $28.78-30.49^{\circ} \mathrm{C} \quad(18.77$ $20.14^{\circ} \mathrm{C}$ )compared to $23.16-25.96^{\circ} \mathrm{C}\left(15.08-15.81^{\circ} \mathrm{C}\right)$ in 1970-2005 and the increase in average maximum and minimum temperature will be $2.68-3.89^{\circ} \mathrm{C}\left(2.85-4.74^{\circ} \mathrm{C}\right)$ from 1970 to 2099 . Mean temperature will rise by $2.76-4.53$ towards the end period. The maximum, minimum and mean temperature will be experienced in the months of July and August.
A linear trend analysis has been performed for maximum, minimum and mean temperature under both the RCPs. Rising trends were observed in all the cases though the trends were not much significant. However, steeper trends were observed under RCP 8.5 compared to those under RCP 4.5.

\section{REFERENCES}

1. IPCC.Climate change and water. Technical paper of the Intergovernmental Panel on Climate Change [Bates B. C., Kundzew Z. W., Wu S., and Palutikof J. P. (Eds.)], IPCC Secretariat, Geneva. 210 p.,2008.

2. N Stern.The Stern Review: Economics of Climate Change. Cambridge University Press, 2006, ISBN- 13: 9780521700801,pp.700.

3. C.P. McMullen, J. Jabbour. (Eds.) Climate Change Science Compendium. UN Environmental Programme, Geneva, 2009, pp.72.

4. S.M. Zarandi, A. Navazi, A.R. Karbassi, S.M.Monavari.A modelling study for predicting temperature and precipitation variations.International Journal of Global Warming, vol.11, no. 4, pp.373, 2017, DOI:10.1504/IJGW.2017.083666.

5. Intergovernmental Panel on Climate Change (IPCC).The Physical Science Basis.Contribution of Working Group I to the Fourth Assessment Report of the IPCC, Geneva, 2007a.

6. Intergovernmental Panel on Climate Change (IPCC).Climate Change 2007: Mitigation of Climate Change. Contribution of working Group III to the Fourth Assessment Report of the IPCC, IPCC, Geneva, $2007 b$.

7. X. Changchun, C. Yaning, L. Weihong.Potential impact of climate change on snow cover area in the Tarim River basin,Environ. Geol.,vol.53, pp. 1465-1474, 2008.

8. Intergovernmental Panel on Climate Change (IPCC).IPCC Fourth Assessment Report- Climate Change 2007: The Physical Science Basis, 2007.

9. N. Rehman, M. Adnan, S. Ali. (2018) Assessment of CMIP5 climate models over South Asia and climate change projections over Pakistan under representative concentration pathways. International Journal of Global Warming, vol. 16. No. 4, pp. 381-415, 2018.

10. Intergovernmental Panel on Climate Change (IPCC).IPCC Fifth Assessment Report - Climate Change 2013: The Physical Science Basis, 2013.

11. R. Mahmood, M.S. Babel.Future changes in extreme temperature events using the statistical downscaling model (SDSM) in the trans-boundary region of the Jhelum river basin, Weather and climate extremes, vol. 5-6, pp. 56-66, 2014.

12. T.F.Q. Stocker, G.K. Dahe, M.M.B. Plattner, S.K.Tignor, J.Allen, A. Boschung, X. Nauels, V.B.Yu, P.M. Midgley.Climate change 2013, the physical science basis.Contribution of working group I to the fifth assessment report of the Intergovernmental Panel on Climate Change, Univ. press, Cambridge, U.K., pp 1533, 2013.

13. W. Steffen,J. Rockstrom, K. Richardson, T.M. Lenton, K. Folke, D. Liverman, C.P. Summerhayes, A.D. Barnosky, S.E. Cornell, M. Crucifix, J.F. Dongos, I. Fetzer, S.J. Lade, M. Scheffer, R. Winklemann, H.J. Schellnhuber.Trajectories of the Earth system in the Anthropocene. Proceedings of the National Academy of Sciences of the United States of America (PNAS), vol. 115, no. 33,pp. 8252-8259, 2018.

14. J. Sathaye , P.R. Shukla, N.H. Ravindranath.Climate change, sustainable development and India: Global and national concerns. Current Science, vol. 90, no. 3, pp. 314-325, 2006. 
Swapnali Barman et al., International Journal of Emerging Trends in Engineering Research, 9(2), February 2021,132 - 139

15. D.R. Kothawale, K.R. Kumar.On the recent changes in surface temperature trends over India. Geophysical Research Letters, vol.32, no. L18714, 2005, doi:10.1029/2005GL023528

16. R. Kumar, H.R. Gautam.Climate Change and its Impact on Agricultural Productivity in India. Journal of Climatology \& Weather Forecasting, vol. 2, no. 1, 2014, DOI: 10.4172/2332-2594.1000109

17. A. Mondal, D. Khare, S. Kundu. Spatial and temporal analysis of rainfall and temperature trend of India. Theor. Appl. Climatol., vol. 122, pp.143-158, 2015.

18. S.K. Dash, N. Sharma, K.C. Pattnayak, X.J. Gao, Y.Shi.Temperature and precipitation changes in the north-east India and their future projections. Global and Planetary Change, vol. 98-99, pp.31-44, 2012.

19. R. Dutta.Climate change and its impact on tea in Northeast India. Journal of Water and Climate Change, vol. 5, no. 4, pp. 625-632, 2014.

20. S.K. Jain, V. Kumar, M. Saharia.Analysis of rainfall and temperature trends in northeast India. International Journal of Climatology, vol. 33, pp. 968-978, 2013.

21. B.A. Choudhury, S.K. Saha, M. Konwar, K. Sujith, A. Deshamukhya.Rapid Drying of Northeast India in the Last Three Decades: Climate Change or Natural Variability?Journal of Geophysical Research: Atmospheres, $\quad$ vol. 124, no. 1, 2018,DOI:10.1029/2018JD029625.

22. S.Z. Samadi, G. Sagareswar, M. Tajiki. (2010) Comparison of general circulation models: methodology for selecting the best GCM in Kermanshah synoptic station, Iran. International Journal of Global Warming, vol. 2, no. 4, pp. 347, 2010. DOI:10.1504/IJGW.2010.037590.

23. S.I. Laskar, S.D. Kotal, S.K.R. Bhowmik.Analysis of rainfall and temperature trends of selected stations over northeast India during last century. Mausam, vol.65, no.4, pp. 497-508, 2014.

24. M. Oza, C.M.Kishtawal. Trends in rainfall and temperature patterns over north east India. Earth science India, vol. 7, no. IV, pp. 90-105, 2014.

25. P.J. Das.Rainfall regime of north east India: emphasis on the Brahmaputra basin. Ph.D. thesis, Gauhati University, 2004.
26. T. Dorji, T.B. Tamang. Report on the analysis of historical climate and climate projection for Bhutan. National Council for Hydrology and Meteorology, Royal Government of Bhutan, 2019.

27. A. Hoi, O. Katel, P. Thapa, N. Dendup, J.Matschullat. (2016) Climatic change and their impact on socio-economic sectors in the Bhutan Himalayas: an implementation strategy. Regional environmental change, vol. 16, pp. 1401-1415, 2016 